\title{
CONTENTS AND WASTE HANDLING OF GREEN SHELL SKIN IN CILINCING, NORTH JAKARTA
}

\author{
Tjipto Rini \\ School of Health Polytechnics Jakarta II, Ministry of Health, Jakarta
}

\begin{abstract}
Background: The seafood industry produces over 100 million pounds of seashell waste every year. With landfillspace diminishing quickly, ways to recycle waste materials are becoming more sought. This happened in Cilincing, Indonesia. There were piles of green shell skin up to 2 to 4 meters. Green shell skin waste can be used as material to make paving block. It can be solution to handle green shell skin waste. This study aimed to analyze the contents and waste handling of green shell skin in Cilincing, North Jakarta.

Subjects and Method: This was a descriptive qualitative study conducted at Cilincing, North Jakarta. The study theme was contents and waste handling of green shell skin. The green shell skin waste was processed into paving blocks. The stages of this process included: (1) Green shells skin washed and dried; (2) Grind skin until became sand; (3) Mix $2 \mathrm{~kg}$ of green shell sand $+1 / 2 \mathrm{~kg}$ cement + $5 \mathrm{ml}$ additive foam concrete $+1 / 2$ litre of water; (4) Put the mixture into a paving block mold size $6 \mathrm{~cm} \mathrm{x}$ $22 \mathrm{~cm}$; (5) Wait for 12 hours; and (6) Strength test. The strength test was done by dropping both green shell skin and ordinary paving block from 2 to 3 meters height.

Results: Green shell skin contained Calcium (36.7\%). Processed green shell skin waste into paving block was an effective way to handling the waste. Both green shell skin and ordinary paving blocks had the same strength.

Conclusion: Green shell skins contain Calcium (36.7\%). Processed green shell skin waste into paving block is an effective way to handling the waste. Green shell skin provides the same strength as the ordinary paving blocks.
\end{abstract}

Keywords: green shell skin, paving block

Correspondence:

Tjipto Rini. School of Health Polytechnics Jakarta II, Ministry of Health, Jakarta. Email: tjiptorini58@gmail.com. Mobile: o82132346563

\section{BACKGROUND}

One of the duties and functions of Community Health Center (Puskesmas) is through Public Health Effort Program. It is an effort in order to make individual, family and community including business sector to have awareness, willingness, and capability to serve themselves and community to life healthily, actively contribute in striving for health purpose, including the fund source, as well as contribute in determining, organizing, and monitoring the implementation of health program. The personal, family and community empowerment is organized by considering situation and condition, especially local community's culture and social.
In the working area of Cilincing Subdistrict Community Health Center, there is a green mussel processing center. They detach and process the mussel meat and dispose the shell waste in that same place. The process has been going on for decades, and it generates heaps of green mussel shell waste which stand $2-4$ meters. The condition is actually distressing the community in the neighborhood, however they do not know how to dispose the waste properly, therefore they let it happen.

Green mussel shell contains $95.69 \%$ of Calcium Carbonate. Calcium carbonate is in a form of solids in white color. One of the advantages of Calcium Carbonate is as the 
material for chalk. Therefore, calcium carbonate is often called as chalk (Siregar, 2009). Calcium carbonate is a chemical compound with formula $\mathrm{CaCO}_{3}$. This compound is a material generally found in rocks in every part of the Earth and also the main component of shell of sea organism, and of snail, charcoal balls, pearl and egg shell. Calcium carbonate is an active substance in agricultural lime, and it is made when $\mathrm{Ca}$ ion in hard water reacts against carbonate ion creates lime scale. It is usually used in medicine as calcium supplement or as antacid, however excessive consumption may be harmful.

The main utilization of calcium carbonate is in construction industry, both as building material and limestone aggregate for road building, as cement material or as the initial material for forming calcium builder by burning it in a kind of hearth. However because of corrosion due to acid rain, limestone is no longer used for building and only used for the main ingredients for construction materials. Calcium carbonate is often used as paint extender which has certain matte emulsion in which either calcium or marble make up 30\% weight of the paint.

Considering the facts elaborated above, it is necessary to immediately conduct the serious management of green mussel shell waste that piling up in Kampung Baru Cilincing. Therefore, the first step is by identifying the content of green mussel shells and inviting the community to utilize the waste.

\section{SUBJECTS AND METHOD \\ 1. Study Design \\ This was a descriptive qualitative study cond- ucted at Cilincing, North Jakarta.}

\section{Population and Sample}

The population of the study was people who live in Meeting Hall of Kampung Baru Cilincing, North Jakarta. The sample of the study was a number of people who joined during the study.

\section{Stages of the Study}

Sample of green mussel shell underwent laboratory test to find out the calcium content. After knowing the content of the shell the researchers visited the location that was at RW 11 Kali Baru, Cilincing.

The inhabitants of the neighbourhood were invited through the heads of RW/RT, to attend a meeting in one of the meeting halls. The researchers afterward gave information related to the content of green mussel shell waste and how to countermeasure it.

\section{The Making of Paving Block out of Green Mussel Shell Waste}

One piece of paving block with the size of 6 $\mathrm{cm} \mathrm{x} 22 \mathrm{~cm}$ is mixed with $2 \mathrm{~kg}$ of green mussel shell sand $+1 / 2 \mathrm{~kg}$ of cement $+5 \mathrm{ml}$ of additive foam concrete $+1 / 2$ litter of water.

\section{RESULTS \\ 1. The Content of Green Mussel Shell}

The result of analysis on chemicals contained by green mussel shell was $95.69 \%$ of calcium carbonate. Meanwhile there was only 36.9\% calcium contained. The other chemicals were not tested since the researcher only intended to know the calcium content that may be used as cement substitute.

\section{Community's Respond Related to Paving Block Production}

a. The weight of paving block produced from green mussel shell is similar with the weight of paving block sold in building material store.

b. Community gladly accepted the production of hati paving block. 


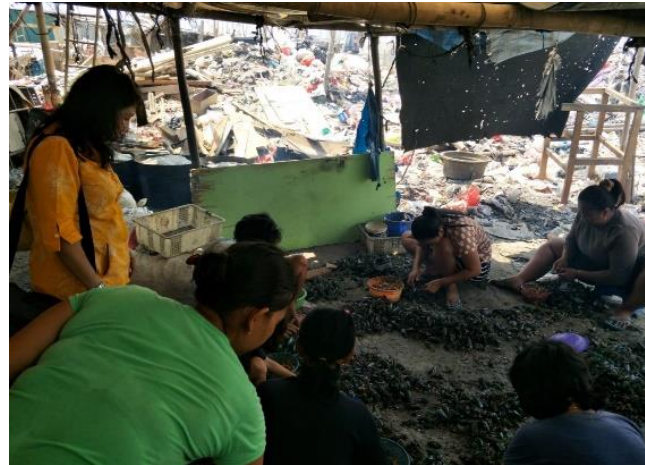

Figure 1. Workers (local people) were detaching the meat from the green mussel shells

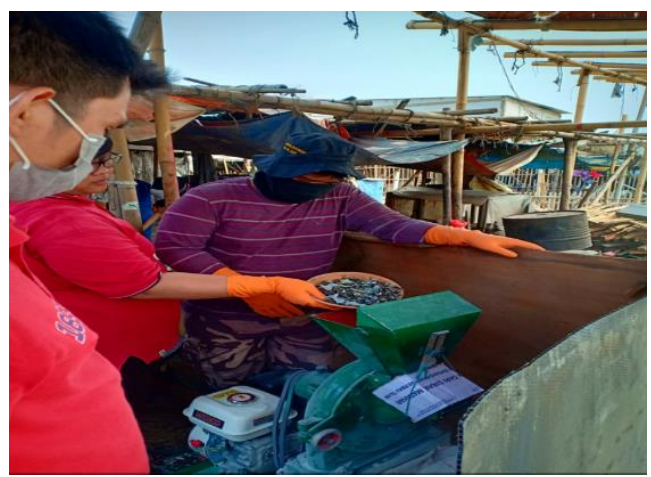

Figure 3. Crushing green mussel shells by using machine into shell powder/sand

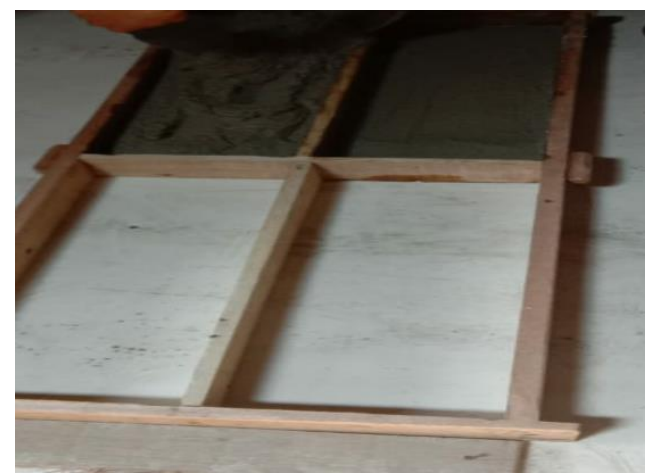

Figure 5. Molding the mixture of shell powder/ sand + cement + additive foam concrete

\section{DISCUSSION}

After paving blocks were molded and sun dried, then they were weighed and it weighed $4.67 \mathrm{~kg}$, whereas paving blocks sold in building material store weigh $4.55 \mathrm{~kg}$. It indicated that green mussel shell can be used as

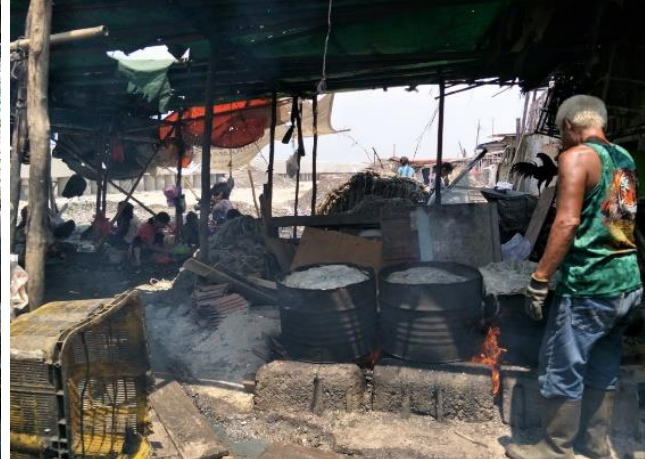

Figure 2. Boiling green mussel

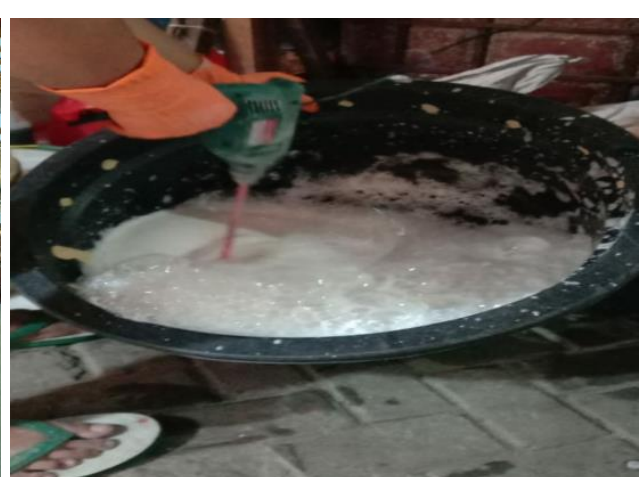

Figure 4. Mixing shell powder/sand

+ cement + additive foam concrete

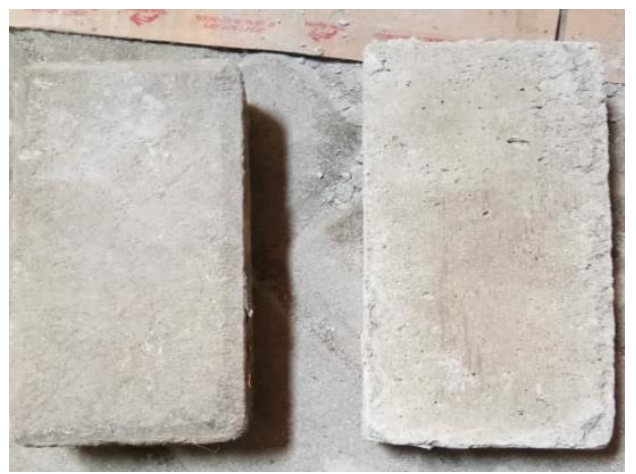

Figure 6. Comparing the result of the study (right) and paving block sold in building material store (left)

cement substitute, which is in line with a study by Alfred et al. (2015) which states that green mussel shell is an eco-friendly substitute material for cement.

According to Helmy et al. (2019) sea shell waste can be used as the concrete aggre- 
gate or commonly known as gravel. They are successful in utilizing sea shell waste as the substitute for concrete aggregate. Concrete made from the waste is suspected to be light weighted and high quality.

The study did not yet test the compressive strength between paving block made from green mussel shells and paving block sold in building material store, however the result of study is in line with a study by Eddy Samsuruzal (2016) which states that sea shells is appropriate as the substitute material for coarse aggregate in the concrete mixture with composition of seashells is $38.45 \%$. The older the concrete is the stronger the compressive strength will be. The value of compressive strength may reach the planned compressive strength, even though it is lower than normal concrete.

\section{REFERENCES}

Alam (2011). Kerang Hijau (Perna Viridis L.). Retrieved from http://karyatulisilmiah.com/kerang-hijau-perna-viridisl/.

Ade SR, Rahmi K (2010). Pengaruh Substitusi Abu Kulit Kerang Terhadap Sifat Mekanik Beton (Eksperimental). Skripsi, Sumatra Utara: Jurusan Teknik Sipil, Universitas Sumatra Utara Medan

Dinas Kesehatan Jakarta (2016). Profil Kesehatan Provinsi DKI Tahun, 2016.
Frieska AS, Dyah S (2013). Studi Eksperimental Pembuatan Ekosemen Dari Abu Sampah dan Cangkang Kerang Sebagai Bahan Alternatif Pengganti Semen". Tugas Akhir, Surabaya: Jurusan Teknik Fisika, Institut Teknologi Sepuluh Nopember.

Othman NA, Bakar A, Don MM, Johari MAM (2013). Cockle Shell Ash Replacement for Cement and Filler in Concrete. Malaysian Journal of Civil Engineering, Penang: University Sains Malaysia.

Sakti HRC, Devayanti A, Akbar AF (2019). Manfaat Limbah Kerang Sebagai Agregat Beton. Retrieved from https://www.its.ac.id/

Samsurizal E, Supriyadi A (2016). Pengaruh Tambahan Cangkang Kerang Terhadap Kuat Beton. Fakultas Teknik Sipil Universitas Tanjung Pura

Sirigar SM (2009). Pemanfaatan Kulit Kerang dan Resin Epoksi Terhadap Karakteristik Beton Polimer. Tesis, Sumatra Utara: Jurusan Fisika, Universitas Sumatra Utara Medan

Sutikno (2003). Panduan Praktek Beton, Surabaya: Universitas Negeri Surabaya

Trihono (2005). Manajemen puskesmas berbasis paradigma sehat. Jakarta: Sagung Seto. 